\title{
Ethnic and Religious Tolerance: Barrier Factors and Improvement Measures Based on Malay Youth Perspectives in Malaysia
}

\author{
Zahrul Akmal Damin ${ }^{a}$, Kamarulnizam Abdullah ${ }^{b}$ and Mohd Sofian Omar-Fauzee \\ A \\ Centre for General Studies and Cocurricular, Universiti Tun Hussein Onn \\ Malaysia, 86400 Parit Raja, Batu Pahat, Johor \\ ${ }^{\mathbf{b}}$ School of International Studies, Universiti Utara Malaysia, \\ 06010 Sintok, Kedah \\ 'School of Education and Modern Languages, Universiti Utara Malaysia, \\ 06010 Sintok, Kedah
}

Article History: Received: 11 January 2021; Accepted: 27 February 2021; Published online: 5 April 2021

\begin{abstract}
Ethnic and religious unity is a thing that every country wishes for not exempting Malaysia. Tolerance among the population is very much expected to achieve this. Nevertheless, ethnic and religious diversity in Malaysia is often seen as a challenge for realizing tolerance and thus creating unity. Therefore, this paper aims to analyze the barrier factors for ethnic and religious tolerance while at the same time identifying proposals for improvement measures to tolerance among the community. Hence, the Focus Group Discussion or FGD study design was used by involving 20 Malay youth informants as information providers. As a result of the analysis it can be concluded that there are six themes that exist as a barrier factor to ethnic and religious tolerance, namely (i) social gap; 38.06 percent, (ii) political debate; 16.42 percent, (iii) religious differences; 16.42 percent, (iv) economic inequality; 11.94 percent, (v) rights and constitution; 11.94 percent, and (vi) primordial sentiment; 5.22 percent. Meanwhile, in addressing the problem of ethnic and religious tolerance, the informants also proposed four perspectives on improvement measures i.e. (i) social empowerment; 71.19 percent, (ii) political role; 15.25 percent, (iii) the rule of law; 10.17 percent, and (iv) maintaining the image of Islam; 3.39 percent. The issues are important to be scrutinized because the practice of good ethnic and religious tolerance can unite the community, thereby driving the stability and progress of the country.
\end{abstract}

Keywords: religion; ethnic; barrier factors; enhancement measures; tolerance

\section{Introduction}

Malaysia which consists of West Malaysia (Peninsular Malaysia) and East Malaysia (Sabah and Sarawak) is a unique country because there are various ethnic and religious groups (Mohd Azmir, 2015). Peninsular Malaysia is famous for its multi-ethnic groups such as Malays, Chinese and Indians as well as the aborigines such as Negrito, Senoi and Proto Malay, while in East Malaysia, Sabah is famous for its 32 ethnic tribes such as Kadazan-Dusun, Murut, Bajau, Suluk and Bisaya. Consecutively, in Sarawak there are 20 ethnic tribes such as Iban, Murut, Kelabit, Melanau and Kadayan (Zahrul Akmal et. al, 2016). From the aspect of beliefs or religion, Malaysians are practicing the teachings of Islam, Buddhism, Hinduism, Christianity and animism (Shamsul Amri, 2012). As a Developing Country, Malaysia despite its diverse ethnics and religions, crave for a strong nation. Thus, ethnic and religious tolerance is the primary means of unifying the Malaysian multi ethnicity citizens (Nur Farhana \& Khadijah, 2013). This is a prerequisite for Malaysia to go ahead with ensuring the harmony of life as well as ensuring national security. Since the independence on August 31, 1957 and the formation of Malaysia on September 16, 1963, Malaysia has taken various steps either top-down approach or bottom-up approach to promote tolerance. Despite celebrating the 61st anniversary of independence, Malaysia is still trying to strengthen the nation based on ethnic and religious tolerance. Only through a harmonious life and a peaceful country Malaysia will achieve the developed nation status.

\section{Problem Statement}

Malaysia as a country comprising ethnic and religious aspects has a challenge in managing its diversity (Sarjit, Mohd Rahimi \& Ahmad Tarmizi, 2015). This diversification is capable of disturbing the stability of the country if there is no tolerance between ethnic and religious populations. Efforts to build a strong nation to achieve the status of a developed nation will face the risk if three issues involving ethnicity and religion are not addressed. The issues are (i) the spread of social contracts, (ii) ethnocentrism and prejudice, and (iii) primordial sentiment. Firstly, issues involving the development of social contracts if not contained will threaten ethnic and religious stability in Malaysia (Mohd Azrone, 2018; Rokiah, 2018; Teo, 2018). It is evident that four things in the social contract that have been constituted as a constitutional basis are often meddled by non-Malays and Bumiputeras. The topics that are often challenged are Article 3 (1) concerning the position of Islam, Article 32 (1) concerning the position of 
the Malay Rulers, Article 152 (1) concerning the Malay language as the national language, and Article 153 (1) concerning Malay and Bumiputera privileges (Nazri \& Ahmad Hidayat, 2012). Secondly, ethnocentrism and prejudice issues are also seen as a threat to Malaysians (Fazilah, Mohd Richard Neles, Abdul Razak \& Ahmad Zamri, 2016; Khairul Anuar, Jessica \& Ahmad Azan, 2015; Mahyuddin, 2011). This is because the people who practice this attitude will make judgments based on their point of reference without considering the views of other groups. In addition, the people who practice this attitude also have the potential to make a negative or bad response to ethnic and other religions. Finally, primordial sentiment is seen as a barrier to ethnic and religious tolerance (New, 2016; Nidzam \& Kartini, 2017). The division of labor based on ethnic separation lines has led to the ethnicities in Malaysia, especially Malays, Chinese and Indians alienated economically and socially. In addition to this issue, these ethnic groups were also at varied settlements either in urban or rural areas. Due to the emergence of these three issues, it has led to a question of the status of ethnic and religious tolerance in Malaysia in terms of awareness, barrier factors and proposed tolerance measures.

\section{Research Objectives}

(1) Analyze ethnic and religious tolerance barrier factors from Malay youth perspectives in Malaysia.

(2) Identify suggestions for ethnic and religious tolerance from Malay youth perspectives in Malaysia.

\section{Theorethical Debates}

Various theories have been introduced to understand the plural society in the world such as Class Theory, Rational Choice Theory and Theory of Plural Society. Class Theory developed by Cox (1948) concludes that racial and ethnic relations that take place in the United States are based on class and caste systems. Cox notes that there is a social gap due to the prejudice of white people and the capitalists against black people and the working class. Disputes occur when the capitalists exploit the working class to benefit from industrial companies. Thus, there exists a system that promotes inequality in social systems by exhibiting social structure divide to white-minded people who own the industry while black-skinned people act as workers. Meanwhile, Rational Choice Theory was popularized by Rabushka and Shepsle (1972) as a result of the development of Thomas Hobbes philosophy in America. The doctrinal standpoint of this theory is that individual actors have the goal of optimizing their will and it is impossible for every individual to fulfil all his wishes. Therefore, individual actors will make rational choices for each alternative or option available to achieve the best choice. When an individual actor has finalized his choice, this means that the alternatives or other options are closed. So based on this theory, individual actors are assumed to act to maximize material rewards and social standing in society based on rational choices. A set of individual actors acting on the same choices will create social bonds over common interests (Hecher, 2011). Moving on, the Plural Society Theory was pioneered by Furnivall (1948) and Smith (1965). The observations made in Burma and India outline the issues of rigid society based on human linking. The description of the plural society is seen as a group of people who mingle but not united. Groups that are in the community are seen adamant to their culture, religion and way of life which cause them to be separated although they are sharing the same living space. Furnivall and Smith stressed that this complex society is described to have a side-by-side life but with a line of separation. In the field of economy, the plural society exhibited a clear division of labour based on race and ethnicity (Shamsul Amri, 2012). As such, among the three theories (Class Theory, Rational Choice Theory and Plural Society Theory) it is found that the Plural Society Theory by Furnivall (1948) and Smith (1965) is seen to have the similar characteristics with the people in Malaysia today. It is because Malaysians also have ethnic diversity in their own culture as well as in their respective religious divisions as a living guide. Additionally from the economic point of view, Malaysia has been following a division of work on the basis of divide and rule introduced by the British from 1874 and this specialization of the work seems to have been inherited although Malaysia had achieved independence in 1957. However, the use of the Plural Society Theory needs to be reexamined as the study by Hefner (2001) finds that the lives of the societies separately today are inadmissible.

\section{Methodology \\ Research Methodology}

Qualitative research approach has been adopted to answer the objectives of the study as suggested by Zhang and Wildemuth (2015). This qualitative approach is seen to be able to explain and give a precise picture of the features found in a phenomenon. This is supported by Creswell (2012) specifying a qualitative research approach aimed at creating the meaning of a phenomenon. While Patton (2002) also asserted that qualitative approach also enables researchers to approach, understand and explain phenomena that occur in society.

\section{Research Design}

In the success of this study, researchers have been using the Focus Group Discussion design or FGD. Discussions are conducted face-to-face with FGD informants and partially structured questions. Partially structured FGDs were used to allow detailed data to be obtained regarding ethnic and religious tolerance in society. It is based on explanations of Schensul, Schensul and LeCompte (1999) that semi-structured FGD discussions are best for clarifying factors and subfactors in the study. 


\section{Research Sampling}

A total of 20 samples from Malay youth between the ages of 18 and 40 years old were selected for this study. Selected participants have agreed to be involved in the FGD on a voluntary basis. The samples were chosen to represent four zones in Peninsular Malaysia, five samples for each zone, namely East (Terengganu), West (Kuala Lumpur), North (Kedah) and South (Johor). According to Carlsson, Lannerstrom, Wallman and Holmstrom (2015), a sample of three to seven people is practical for every FGD session. Meanwhile, from the background of the sample, they are university students, government staff and private workers.

\section{Research Instrument}

Partially structured interviews conducted were built by researchers based on literary studies that have been made to answer the objectives of the study. The introduction section covered the informants' background information, the main section addressed the research objectives and the closure section was for additional information. Meanwhile, in the main section there were two categories namely the core questions and the probe questions. The FGD questions that were addressed to informants are as Table 1.

Table 1

FGD Interview Questions

Question Section

Introduction

Objective 1

Objective 2
Please explain your background.

\section{Core Question}

What is the barrier factor to ethnic and religious tolerance in Malaysia?

Probe Question

The people's dispute is linked to ethnic and religious differences? What is your opinion? Conflicts occur as a result of inequality. What is your opinion?

Is negative impression on ethnicity and religion a barrier factor to tolerance?

Is difficulty in interaction a factor that causes lack of tolerance?

\section{Core Question}

How to make each ethnicity and religion tolerate better?

\section{Probe Question}

What measures can be taken by the government to improve the ethnic and religious tolerance?

What measures can be taken by the society to improve ethnic and religious tolerance?

Closure

\section{Research Procedure}

Is there anything else you want to add regarding tolerance of race and religion??

In the early stage, researchers have circulated a consent letter to informants to undergo FGDs in voice recording. Only informants who signed the letter of consent were invited to become members of the closed FGD. In conducting FGD, researchers have appointed a moderator among Malay youth to conduct interviews. Each informant was briefed on the purpose of the study as suggested by Nyumba, Wilson, Derrick and Mukherjee (2018) and the informant was also given the opportunity to withdraw at any time without prejudice. Informants were also informed that all information is confidential and their names would be kept confidential.

\section{Data Analysis}

The recorded FGD interviews have been transcribed in the form of MS Word 2013 and sent back via e-mail to informants for verification purposes. Transcripts that have undergone the verification process were finally analyzed at the word, phrase and sentence levels related to the research objectives as proposed by Berg (2007). Through the following set of data, the data required to answer the objectives of the study can be accomplished (Sabitha, 2006). The data were then analyzed and illustrated using the performance framework by Weiss, Smith and Theeboom (1996) and Zahrul Akmal (2016).

\section{Findings and Discussion}

Barrier Factors towards ethnic and religious tolerance from the perspectives of Malay youths in Malaysia

The result based on the responses given through the FGD involving 20 Malay youth informants, the analysis found that there were six main themes that became the barrier factor of ethnic and religious tolerance in Malaysia. The themes were developed based on 134 raw data items which were studied in frequency, and they are (i) social gaps, 51 frequencies or 38.06 percent, (ii) political conflicts, 22 frequencies or 16.42 percent, (iii) religious differences, 22 or 16.42 per cent, (iv) economic inequality, 16 frequencies or 11.94 per cent, (v) rights and constitutions, 16 frequencies or 11.94 per cent, and (vi) primordial sentiment, 7 frequencies or 5.22 per cent as shown in Table 1 and Table 2 .

\begin{tabular}{|l|l|r|}
\hline RAW DATA & SUBTHEME & THEME \\
\hline \hline School segregation (3) & & \\
It's as if to make a Chinese place (1) & & 624 \\
\hline Instability of the Education system (1) & & \\
Change religious school to church (1) & & \\
\hline
\end{tabular}


Chinese proactive, Malays not proactive (3)

Some are stabbed in the back (2)

Chinese, Indians are moving to topple the Malays (1)

Chinese are pro active to destroy the Malays (1)

Some people take advantage (1)

The Chinese are difficult to communicate with the Malays (3)

Just speak their own language (2)

Indians are not fluent in the Malay language (1)

Chinese curse the Malays in Chinese (1)

'Mind set' of the people respectively (2)

Malaysia is too open (2)

Dailv culture (2)

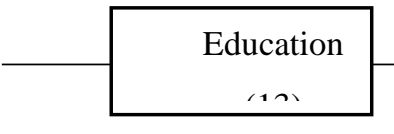

1101

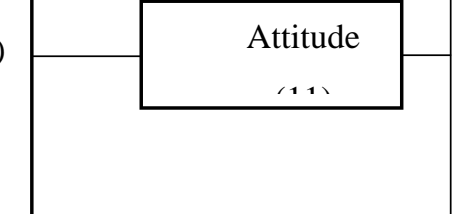

Lack knowledge of other races (2)

The existence of disagreement (2)

The characteristics of the individual itself (1)

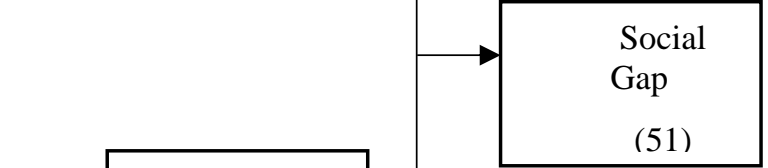

Family (3)

ar a

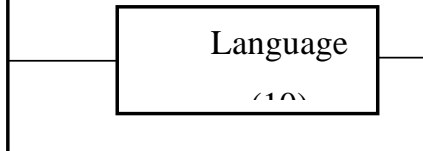

Starting from the politicians themselves (3)

Leaders care too much about tolerance (3)

People above us are non Malays (3)

Top leader is the issue (3)

We have our own leaders (3)

Political System (2)

Everyone is hustling to rule the country (1)

Chinese cemetery (land snatching) (3)

Azan should not be called loudly (3)

Lack knowledge of other religions (2)

Do not know the Islamic laws (2)

Christians organize parties (2)

Fight for a place for religious events (1)

Family

(1)

Way of

life (7)

Individual

(r)

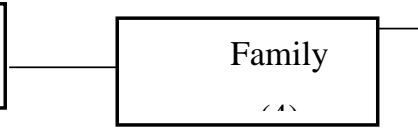

Organize a religious concent, but there are dances (1)

There are incense; many people are angry (1)

Drive the illegal lorry, disturbing (1) 
Malays are choosy about jobs (4)

Chinese does not want to hire Malays (3)

Private sector; Malays are totally oppressed (2)

The Chinese economy has no halal law (2)

Chinese salary is much more than Malays (1)

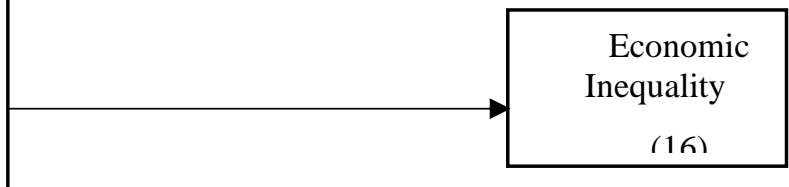

Chinese companies take Chinese people (1)

Keep the rights of the Malays (3)

Privilege rights must be retained (2)

The rights of the Malays are given to the Chinese (1)

The Malay reserve land has disappeared (1)

Support Malays' rights abolished (1)

Malays' rights are given to others (1)

Malays' scholarships have been withdrawn (1)

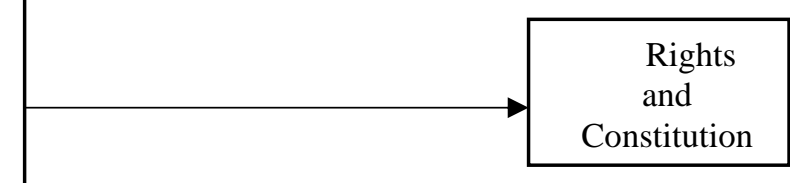

Scholarship to be given equally (1)

Malays' rights are taken (1)

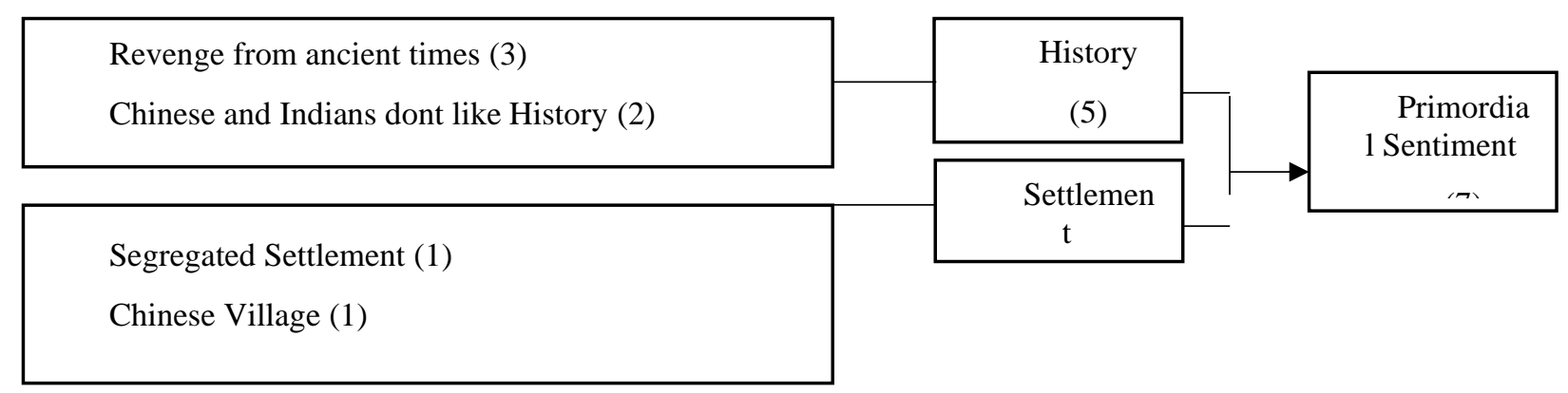

Chart 1: Barrier factors towards Ethnic and Religious Tolerance from Malay Youth Perceptions

Table 2

Barrier factors towards Ethnic and Religious Tolerance based on Themes,

Frequency and Percentage

\begin{tabular}{llcc}
\hline No. & Themes & Frequency & Percentage \\
\hline 1 & Social Gap & 51 & 38.06 \\
2 & Political Conflicts & 22 & 16.42 \\
3. & Religious Differences & 22 & 16.42 \\
4 & Economic Inequality & 16 & 11.94 \\
\hline
\end{tabular}




\begin{tabular}{|c|c|c|c|}
\hline 5 & Rights and Constitution & 16 & 11.94 \\
\hline 6 & Primordial Sentiment & 7 & 5.22 \\
\hline & Total & 134 & \\
\hline
\end{tabular}

Source: FGD Informants

First Theme: Social Gap Factor

The findings show that social gap is a category of themes that has the most frequency that is 51 frequencies. It is the main theme by representing 38.06 percent of the total ethnic and religious tolerance barrier factor in Malaysia. From this theme, there are six sub-themes under it which are (i) education, (ii) attitude, (iii) language, (iv) way of life, (v) individual, and (vi) family, as seen in Table 3.

The development of the educational sub-theme was based on analyzed raw data such as school isolation, as if to make a Chinese place, and unstable educational system. The attitude sub-theme was developed through raw data such as Chinese are proactive, Malays are not, there is back stabbing, and Chinese, Indians moving to topple Malays. Meanwhile, there are some raw data items that were identified as functioning as a formulation of the way of life that is mind set of people, Malaysia is too open, and Chinese group together according to their clans. While for individual sub-themes were built on the basis of raw data support such as lack of knowledge on other races, disagreements, and not understanding ethnicity. Lastly for the family sub-theme, the construction of this sub-theme was backed up with raw data such as family, and we are educated with racial gaps.

Table 3

Theme: Social Gap as a Barrier Factor for Ethnic Tolerance

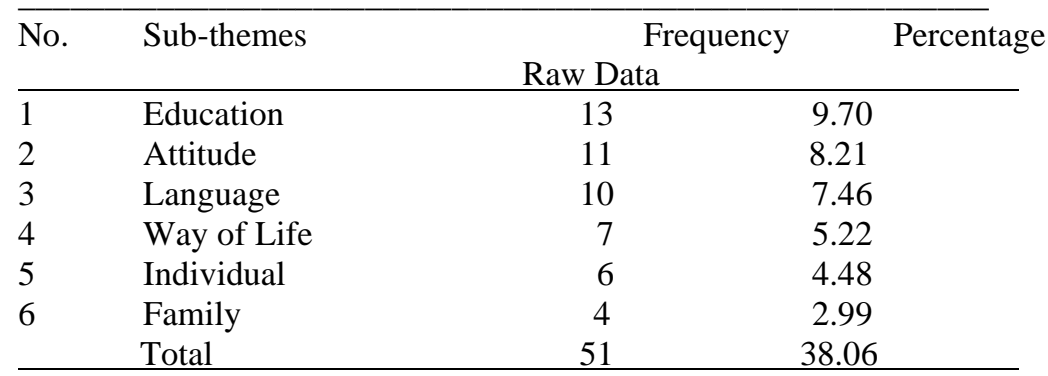

Source: FGD Informants

The theme of social factor shows that there is a social barrier factor to good and harmonious community relations in the context of education. Even Hussein and Hanieza (2017) also acknowledge that the level of racial unity in the country is low. The findings from Southern zone FGD informants are also parallel to the obstacles under the educational sub-theme by stating:

"There is an Indian school ... there is a Chinese school ... there is a national school. Indeed, people will send their children to the national school, but there are still people sending their children to Chinese school ... its ok. So when Chinese go to Chinese school meet with Chinese teacher ... so all Chinese. So there is no tolerance. "

Western FGD informants insisted on the interior of the Malays themselves, "If we look at the Malay parents do not send their children to government schools because they are not sure about the education system in Malaysia." Meanwhile, the Northern FGD informant expressed their concern over tolerance, "If we ourselves look at different schools, the vernacular schools does not produce a Malaysian because each language has their own language, so it is difficult to tolerate them." This view is also agreed by Suzy Aziziyana, Rosila Bee and Khairulnizam (2018) stating that vernacular schools do not help unity.

Meanwhile, in terms of attitudes, Western FGD Informants expressed anxiety over the seriousness of the ethnic Malays themselves, "Chinese are proactive, Malay are not ... they always wait for things that come before them. The Malays are like that. That's why I said, so I say Malays do not like to grab the opportunity. "However, Western FGD informants remain concerned about the relationship between the Malays and Chinese and Indians in terms of tolerance. It is said as follows, "... now Chinese, Indians are increasingly moving slowly to bring down the true Malays." Even studies by Junaidi, Rosmadi, Amer Saifude, Mohd Azlan, Mazlan and Ahmad Rizal (2014) found that young Chinese ethnic groups have tried to dominate politics, especially in strategic cities.

From the language sub-theme, the Northern FGD Informants are in the view that there is still a state of incompetence for the Malay language. He said "... if you want to communicate with ethnic Chinese there is no problem but ethnic Chinese is less fluent in Malay because of the vernacular school education." As language has become a social boundary then there are those who take advantage of this as the experience shared by Eastern FGD informants, namely:

"... for example buying a mobile phone. While buying my mobile, I listen to my friend's friend who speaks Chinese but he is a Malay. He once bought from a shop.... C Chinese shop. When he says that he wants a little bit of discount, the salesperson talks with his boss but he ask the boss if he wants to sell it expensive or cheap. Then the boss said expensive. So we can see a lot bad here. He can fool us with his own language. " 
Moving on, the analysis of the findings also found that the style of living sub-theme contribute to barrier factors to tolerance. The East FGD informant views that "It is sometimes... the thing that prevents tolerance between the Malays, China and India, is the mind-set of their individual, mind-set Malay, Chinese mind-set and mind-set of each of India." This is also supported by Informant FGD Utara, "... on the barrier factor to ethnic tolerance in Malaysia is a factor that I can tell is in terms of their living culture." According to Abdul Rauf, Jusang and AlMansor (2017) mind-set and negative thinking will hinder the harmony of living together as one community.

In parallel with this, there are informants who assert that tolerance barrier factors are contributed by individual sub-theme and family sub-theme. The Northern FGD informant has expressed his anxiety that "... for me is knowledge of other races. Because of the lack of knowledge ... we have become very difficult to tolerate and respect what they do. "The Northern FGD informant also emphasized" ... I think the differences in opinion and views from each ethnicity will contribute to the barrier factor to the tolerance of all ethnicities. "FGD North Informants added" ... the factors that impede tolerance are the upbringing of the family. For example if he is from a family that is educated in order not to tolerate other ethics then he will grow up to be an intolerant."

Second Theme: Political Conflict Factor

With the frequency of support phrases 22 times, the factor of political upheaval is the second-largest theme which contributes to 16.42 percent of the ethnic and religious tolerance barrier factor in Malaysia as shown in Table 4. The development of this theme is based on analyzed raw data such as from own political leader, leaders care too much about tolerance, and our top guns are non-Malays.

Table 4

Theme: Political Conflict Factor as Barrier Factor for Ethnic Tolerance

\begin{tabular}{llcc} 
No. & Subtheme & $\begin{array}{c}\text { Frequency } \\
\text { Raw Data }\end{array}$ & Percentage \\
\hline 1 & Political Conflict & 22 & 16.42 \\
& Total & 22 & 16.42 \\
\hline
\end{tabular}

Source: FGD Informants

An analysis of transcripts found that Northern FGD Informants were very concerned with the management of the latest political system. He finds that "... there is a conflict between ethnic groups in Malaysia which is largely due to the political system in Malaysia. They do not agree and object to the existing system of politics in Malaysia and cause differing opinions and views and cause racial disputes. "Also having the same flow of views is the Central FGD Informant by revealing that" ... exactly what I see, our politics near Malaysia alone that educate this race.... "He adds," I think one of the reasons why this kind of thing started from the politicians themselves.... "This also got the attention of Tiung and Mohd Safar (2015) which emphasizes ethnic differences has been deliberately politicized by a mala fide or bad-intention leader.

Third Theme: Religious Difference Factor

The third largest theme contributing to the barrier factor to ethnic and religious tolerance is the difference in religion. This theme contributes 22 support phrases and represents 16.42 percent as shown in Table 5 . This theme is developed based on raw data such as Chinese cemetery (land snatching), azan should not be called loudly, and lack of knowledge of other religions.

Table 5

Theme: Religious Factor as the Barrier Factor for Ethnic Tolerance

\begin{tabular}{llcc} 
No. & Subtheme & $\begin{array}{c}\text { Frequency } \\
\text { Raw Data }\end{array}$ & Percentage \\
\hline 1 & Religious Difference & 22 & 16.42 \\
& Total & 22 & 16.42 \\
\hline
\end{tabular}

Source: FGD Informants

Southern FGD informants in this case explain their concern about the issue of Chinese cemetery. He states that:

"... There is a hilltop land, so people do not build houses there. The hill is also steep. So they made it as a Chinese cemetery. They bury the dead there because they are trying to get the land there. They are taking the Malays' rights indirectly.

The South FGD informants added, the azan issue that should not be called loudly can also impede tolerance. With Islam as a federal religion, he questioned why the azan should not be called loudly. He expressed his disappointment as follows, "There is, however, the azan should not be sounded. My housing area that time.... Azan cannot as though they are disturbed by the azan. I like ... why cannot azan? Our official religion is Islam. Majority of the people are Muslims." Meanwhile, North FGD Informants insist that lack of knowledge about other religions causes difficulty in tolerance. It is stated that: "... due to lack of knowledge from other religions. It means we do not understand what other religions are like ... so it's hard to tolerate and respect what they do. "

Fourth Theme: Economic Inequality Factor 
With the frequency of support phrases 16 times, the economic inequality is the fourth largest theme contributing to 11.94 per cent of the ethnic and religious tolerance barrier factor in Malaysia as shown in Table 6. The theme was developed through raw data such as Malays are choosy about work, private sector also the same, Chinese do not want to take Malay workers, indeed Malays are totally oppressed.

Table 6

Theme: Economic Factor as Barrier Factor for Ethnic Tolerance

\begin{tabular}{llcc} 
No. & Subtheme & $\begin{array}{c}\text { Frequency } \\
\text { Raw Data }\end{array}$ & Percentage \\
\hline 1 & Economic Inequality & 16 & 11.94 \\
& Total & 16 & 11.94 \\
\hline
\end{tabular}

Source: FGD Informants

Central FGD informant shared his feelings: "Usually private firms, they are totally biased with the Malays. So usually the private is usually Chinese, Indians.... "The view of this informer has been proven by Abdul Razaq (2018) who sees that there is a gap in employment and the economy where Chinese ethnics concentrated more on the private and business sectors. Central FGD Informants added, "... when we look in a small scope for example in private sector, indeed the Malays are totally oppressed in terms of salaries ... in terms of service is very different." The oppression of the ethnic Malays was also sadly shared by FGD Informants South, namely:

"... my mother works in the logistics department. So she is well connected with the Chinese. Chinese or Indians. Most of these jobs are dominated by the Chinese. So they do not want to get Malay workers because to them Malays are bad and Chinese likes to ... what I know is ... Chinese firms will hire only Chinese to work. So they do not want to help develop the Malays because they think the Malays are lazy. Like to take advantage. Not working hard. always late. So they do not want to take Malays. "

Fifth Theme: Rights and Constitution Factor

With the frequency of support phrases 16 times, the rights and constitutional factor is the fifth largest theme which contributes to 11.94 per cent of the ethnic and religious tolerance barrier factor in Malaysia as shown in Table 7. There are several known raw data items as the base of this theme such as privileges must be maintained, the rights of the Malays are given to the Chinese, and the Malay reserve lands are gone.

Table 7

Theme: Rights and Constitution Factor as Barrier factor for Ethnic Tolerance

\begin{tabular}{llcc}
\hline No. & Subtheme & $\begin{array}{c}\text { Frequency } \\
\text { Raw Data }\end{array}$ & Percentage \\
\hline 1 & Rights and Constitution & 16 & 11.94 \\
& Total & 16 & 11.94 \\
\hline
\end{tabular}

Source: FGD Informants

The Northern FGD informant in a statement stated "... what we are aware of, the rights of the Malays are to be defended, as Malaysia itself is led by the ethnic Malays and the Indians and Chinese came later." Therefore it is no wonder that the Chinese and Indians has a skeptical view of the rights issue as emphasized by the Central FGD Informant "... but it is actually possible that the Chinese has a sense of revenge, dissatisfaction with always the Malay rights, Malay rights, that's why they slowly do not support the Malays rights. But there are Malays who also do not agree with the Malays rights, that's why we are divided. "In a specific issue, the Southern FGD Informant in a state of regret examining the issue of land rights by mentioning" ... near my place there are so many lands ... So they made it as a Chinese cemetery. They bury the dead there so as to get the land there. Indirectly Malays rights are disturbed." However, Mohd Ridhuan Tee (2015) stressed that ethnic Chinese took such an approach just to defend their interests.

Sixth Theme: Primordial Sentiment Factor

The findings show that the primordial sentiment factor is a category of themes which has the smallest frequency support phrases of 7 frequencies. This theme represents 5.22 percent of the total ethnic and religious tolerance barrier factor in Malaysia. From the sixth theme, there are two sub-themes under it which are (i) history, and (ii) settlement as shown in Table 8. The sub-theme history is built on the backing of raw data such as revenge from long time ago, and Chinese and Indians do not like history. Meanwhile, the development of the sub-theme settlement is based on raw data such as isolated settlement, and Chinese villages.

Through interviews with Central FGD Informant, it is found that primordial sentiment based on the subtheme history clearly plays a role as a barrier factor. He criticized that "China is what we see as proactive is working hard to bring down the Malays really. They have always been targeting to rule this country. ... it is like about the issue of revenge. Perhaps this revenge may have come from ancient times. "The study by Jazimin and Sity (2018) found 
that this primordial factor plays an important role in ethnic conflict and it should be avoided in promoting ethnic integration.

Table 8

Theme: Primordial Sentiment factor as barrier factor for Ethnic Tolerance

\begin{tabular}{llcc}
\hline No. & Subthemes & $\begin{array}{c}\text { Frequency } \\
\text { Raw Data }\end{array}$ & Percentage \\
\hline 1 & History & 5 & 3.73 \\
2 & Settlement & 2 & 1.49 \\
& Total & 7 & 5.22 \\
\hline
\end{tabular}

Source: FGD Informants

The Central FGD Informant added, "... mostly Chinese with Indians, they do not like history, never love history, and often ... and what goes out of their mouths, they will manipulate that fact so that we the Malays are the ones who are immigrants. "While from the aspect of the sub-theme of settlement that plays a barrier role, South FGD Informants briefly stated that" School segregation and after that the settlement segregation. "This is further elaborated by the Eastern FGD Informants that" ... from childhood they go to Chinese school and stay in Chinese village. So they think when they stay near the Malay village ... they feel like it's a mistake'.... "

Suggestions towards the Ethnic and Religious Tolerance based on Malay Youth Perceptions

As a result of the responses given by the FGD involving 20 Malay youth informants, the analysis found that there are four main themes which are suggested for ethnic and religious tolerance in Malaysia. The themes are developed based on 57 raw data items which are studied based on the frequency: (i) social empowerment, 42 frequencies or 71.19 percent, (ii) political factors, 9 frequencies or 15.25 percent, (iii) rule of law, 6 frequency or 10.17 percent, and (iv) the factor of maintaining the image of Islam, by 2 frequencies or 3.39 percent as presented in Figure 2 and Table 9.

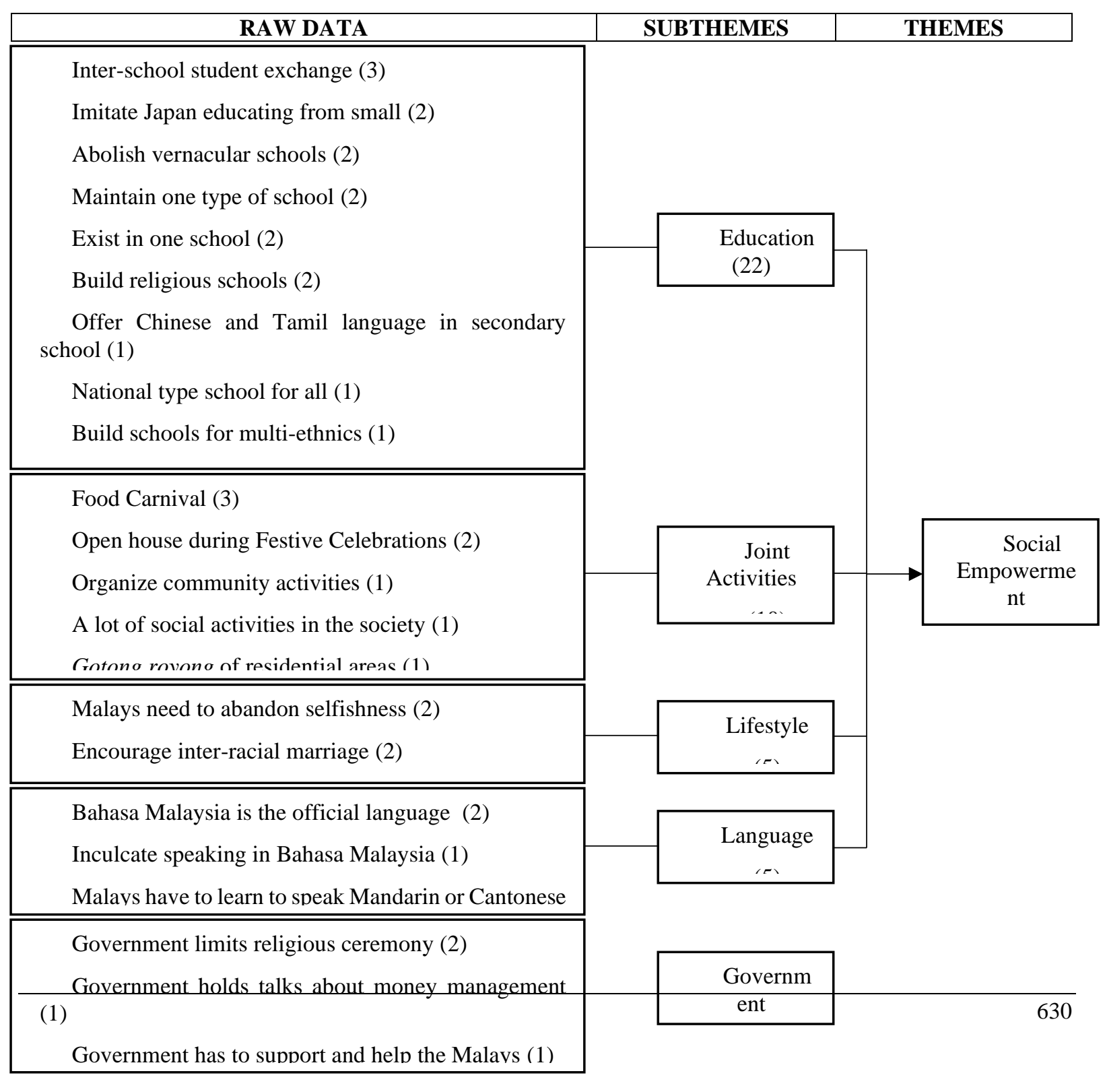




\begin{tabular}{|l|l|l|}
\hline Stop being political racists (2) \\
\hline \hline ISA Act needs to be re-implemented (1) \\
The Act needs to be updated (1) \\
Refer need to be reviewed and formulated (1) \\
Islamic Image (1)
\end{tabular}

Figure 2: Suggestions towards Ethnic and Religious Tolwerance from the Malay Youth Perspectives

Table 9

Suggestions towards Ethnic and Religious Tolerance based on Theme, Frequency and Percentage

\begin{tabular}{llcc}
\hline No. & Themes & Frequency & Percentage \\
\hline 1 & Social Empowerment & 42 & 71.19 \\
2 & Political Role & 9 & 15.25 \\
3 & Rule of Law & 6 & 10.17 \\
4. & Maintaining Islamic Image & 2 & 3.39 \\
& Total & 59 & 100.00 \\
\hline
\end{tabular}

Source: FGD Informants

First Theme: Social Empowerment

The findings show that social empowerment is a category of themes that has the most frequency of support phrases of 42 frequencies. This theme is the main theme by representing 71.19 percent of the total ethnic and religious tolerance proposals in Malaysia. Out of this theme, there are four sub-themes under it which are (i) education, (ii) joint activities, (iii) way of life, (iv) language, as shown in Table 10. Development of educational sub-themes is based on raw data such as inter school student exchange, imitating Japanese educating from childhood, and abolishing vernacular schools. The joint activity sub-themes are developed through raw data such as festive celebrations, open house festivals, and social activities. Meanwhile, there are some items of raw data that are identified as functioning as a formulation of lifestyle that Malays need to abandon their selfishness, encourage inter racial marriages, and Malays try to think positively. While for language sub-themes built on raw data support such as Bahasa Malaysia as the official language, encouraging the use of the Malay language, and the Malays have to learn to speak Chinese.

Table10

Theme: Social Empoerment as Suggestion towards Ethnic and Religious Tolerance

\begin{tabular}{llcc} 
No. & Subthemes & $\begin{array}{c}\text { Frequency } \\
\text { Raw Data }\end{array}$ & Percentage \\
\hline 1 & Education & 22 & 37.28 \\
2 & Joint Activities & 10 & 16.95 \\
3 & Lifestyle & 5 & 8.48 \\
4 & Language & 5 & 8.48 \\
& Total & 42 & 71.19 \\
\hline
\end{tabular}

Source: FGD Informants

In the meantime, FGD interviews have been identified to serve as a basis for the construction of this social factor theme. For educational sub-themes, Southern FGD Informants see that education can be used as an element of improving ethnic and religious tolerance. He states "Education. Like..... Inter-school student exchange ... we have a student exchange from abroad to Malaysia. So what do we say from Malay schools to Chinese schools, Chinese to Tamil ... just like that. So he's like ... ha, he's learning it. "Central FGD informants see examples of 
comparative education from outside the country," But, if Japan ... we see the children being educated from small. Look at them go to LRT, because educated from childhood, they are consistent. "A more critical view has been raised by the Northern FGD Informants to abolish the vernacular school with a firm statement of" abolish vernacular schooling! "The idea is to assemble all races in one school that is a national school, so when they are in one school, they will learn one language and learn to tolerate one another. Noralina (2016) suggested that social interventions through education policies need to be effectively created in schools.

Meanwhile, from the aspect of the joint activity sub-theme, various suggestions have been proposed such as to engage in activities to create ethnic tolerance. Informants of the Northern FGD suggested that people of different ethnics prepare food and eat togtether." The proposal for more activities has also been raised by Southern FGD Informants, "Gotong royong, family day, if at school. Canteen day, make meals, banquet, open house, celebration.... ". The suggestion was also supported by Northern FGD Informants by responding that "... one area needs to make more community activities involving all races. So from there we know more about our neighbors and we are more respectful when we are more acquainted and familiar with them. "The idea is also supported by Adlina, Rosfazila and Hairol Anuar (2018) by detailing that these mutual activities can be used as a medium for the cultivation of noble values at the same time creates a sense of belonging to those involved.

From the sub-theme of lifestyle, the East FGD Informant said that ethnic Malays should have a positive nature to tolerate. Not only look at Chinese ethnics, he suggested that the Malays also change as his view is "If we look at the Malays themselves is a kind of ego, a bad character one, the nature of wanting to see others fail. ... So the Malays have to change. The Malays should look at the Chinese, the Chinese are developing, the Chinese are managing the economy, the Chinese themselves manage their administration. So Malays have to change their perceptions ... to change their behavior. "At the same time, closer tolerance can be made with mixed marriages. The Northern FGD informant through his statement said that "... to encourage more inter racial marriages as possible, the Chinese if they please other races .... And in that sense it may add to the good of the ethnic tolerance itself because of the existence or increase of inter racial marriage...."

Furthermore, the study found that language sub-theme also contributes to promoting tolerance. Northern FGD informant in a serious tone reminisced "... the Malay language is the national language. ... is to nurture them to speak Malay which means no other languages because the Malay language is the official language of Malaysia." A more universal view was also suggested by North FGD Informant to improve the use of language as mentioned in the interview, that is, "... national schools are given exposure to all three languages. Use Malay, Chinese and Tamil languages so that when communicating the gap between the communication can be diminished.... "An earlier opinion was urged by Ghazali and Shamsudin (2014) that the government should seriously look at efforts to improve language proficiency in both primary and secondary schools.

Second Theme: Political Role

The findings show that political roles are the category of themes that have the second highest frequency support phrases of 9 frequencies. This theme represents 15.25 percent of the total ethnic and religious tolerance suggestions in Malaysia. From this theme, there are two sub-themes under it which are (i) the government, and (ii) knowledge of country's politics, as presented in Table 11. For government sub-theme, the development of this sub-theme is based on raw data such as the government limiting the religious ceremony, giving talks on money management, and the government has to help the Malays. Meanwhile, the development of the sub-theme knowledge of country's politics is developed through raw data such as racial politics, and political parties are not in conflict.

Table 11

Theme: Political Role as Suggestion towards Ethnic and Religious Tolerance

\begin{tabular}{llcc}
\hline No. & Subthemes & $\begin{array}{l}\text { Frequency } \\
\text { Raw Data }\end{array}$ & Percentage \\
\hline 1 & Government & 6 & 10.17 \\
2 & Knowledge of country's politics & 3 & 5.08 \\
& Total & 9 & 15.25 \\
\hline
\end{tabular}

Source: FGD Informants

An analysis of transcriptions demonstrates that government sub-theme that is government organizations need to play a role in promoting ethnic tolerance. South FGD informants expressed their views: "in terms of religion, the government can limit its time. Like when there is a ceremony. It has to be limited. "This step is necessary as there is a situation where religious ceremonies have been disturbing the well-being of the population. However, the Eastern FGD Informants see with a different perspective although it still touches the role of the government. He noted that ethnic Malays should be assisted especially in terms of financial management. The following opinion can be seen in the statement "... my proposal is government to play an important role to help the Malays." He added, "... so maybe the government can organize a talk on how to manage money."

In another aspect of the sub-theme knowledge of country's politics, Northern FGD Informant sees actors and political parties should also play a function to promote tolerance. It is emphasized in the interview that "every 
politician appointed by the people, whether in the opposition or government should stop bringing up racial politics because it is unprofitable for any party, it is just like burning gasoline into the fire to fuel the fire itself ... "The views on the aspects of the knowledge of country's politics are voiced as" ... political parties should not be in disagreement, but rather to question the voices and opinions of the people in order to further improve the integrity of the people ... "So Siti Shariyah, Junaidi and Mohd Fuad (2017) propose that political literacy should be improved so that a good understanding of political science can be realized.

Third Theme: Rule of law

With the frequency of support phrases 6 times, the rule of law is the smallest theme that contributes a breakdown of 10.17 percent to the ethnic and religious tolerance barrier factor in Malaysia as shown in Table 12 . The development of this theme is based on raw data such as the ISA Act that needs to be re-implemented, the Acts need to be updated, reviewed and be formulated.

According to Central FGD Informants, laws such as the Internal Security Act (ISA) need to be re-implemented. This is evidenced when he suggested that "I think that the ISA Act should be called back." Furthermore, Central FGD Informant added that "... what I see, we have the laws ... we need it to be formulated .... There seems to do good for the people. "The emphasis on this act is seen to be able to create better tolerance as he once again stated that" ...he had to look at the rules first, see first the Act.... "As explained by Bilveer (2015), Malaysia without ISA will expose the state of terrorism and thus Malaysia needs a strict legal approach in ensuring security is assured.

Table 12

Theme: Rule of Law as Suggestion towards Improving Ethnic and Religious

Tolerance

\begin{tabular}{llcc}
\hline No. & Subtheme & $\begin{array}{l}\text { Frequency } \\
\text { Raw Data }\end{array}$ & Percentage \\
\hline 1 & Rule of Law & 6 & 10.17 \\
& Total & 6 & 10.17 \\
\hline
\end{tabular}

Source: FGD Informants

Fourth Theme: Maintaining Islamic Image

The findings show that maintaining the image of Islam is a category of themes that has the smallest support phrase frequency of 2 frequencies. This theme represents 3.39 per cent of the overall factor of the ethnic and religious tolerance suggestions in Malaysia as shown in Table 13. The theme of maintaining the image of Islam is built on raw data such as our image and Islam image as affirmed by Southern FGD Informants, so this thing depends on our self. We portray our image as a Muslim. The image of Islam. "

Table 13

Theme: Maintaining Islamic Image as Suggestion towards Improving Ethnic and Religious

Tolerance

\begin{tabular}{llcc}
\hline No. & Subtheme & $\begin{array}{l}\text { Frequency } \\
\text { Raw Data }\end{array}$ & Percentage \\
\hline 1 & Maintaining Islamic Image & 2 & 3.39 \\
& Total & 2 & 3.39 \\
\hline
\end{tabular}

Source: FGD Informants

\section{Conclusion}

Research Summary

The findings to address the first objective of the study found that social gap factor (38.06 percent) is the most important theme which serves as a major barrier to ethnic and religious tolerance in the perspective of the Malay youth. This is followed by other themes of political conflict (16.42 percent), religious differences (16.42 percent), economic inequality (11.94 percent), rights and constitution (11.94 percent), and primordial sentiment (5.22 percent). This discovery is important to enable every ethnicity and religion to know the do's and don'ts in a diverse society in Malaysia. In parallel with these findings, FGD Informants also provide recommendations that need to be considered seriously to improve tolerance among ethnic and religious groups whereby it addresses the second objective of the study. They have suggested that social empowerment (71.19 percent) such as education, joint activities, way of life and language are emphasized more precisely among the various ethnic communities. Among others, FGD informants also suggested that political roles (15.25 percent), rule of law (10.17 percent), and maintaining the image of Islam (3.39 percent) should also be emphasized by the ruling community and government.

\section{Limitation of Study}

This study applies FGD designs among Malay youths only. Therefore, the views of Chinese and Indian youths should be involved in obtaining an overview of the existing youth in Malaysia regarding ethnic and religious tolerance. In addition, further studies on ethnic and religious issues are also recommended to use survey techniques. 
This is because this technique may involve the accumulation of larger amounts of data. In line with that, the generalization of the diverse ethnic and religious views is possible.

\section{Implication of Study}

The findings suggest that education should be emphasized to the younger generation. In this regard, development of ethnic and religious tolerance can be instituted both at primary and secondary school levels. It is recommended that ethnic relations topics be included in the syllabus of the History or Moral Education subjects. Drastic measures can also be taken by implementing national schools as the mainstream. It can be accomplished by empowering national schools and simultaneously closing national-type schools in stages. This is seen in line with the views of the FGD Informants that the vernacular schools need to be closed. By conducting this student exchange program it will encourage every children of different ethnics to learn and understand about cultures and religions from other ethnicities.

\section{Acknowledgement}

The study of "Ethnic and religious Tolerance: Barrier factors and improvement measures based on Malay youth perspectives in Malaysia" is carried out using the provisions of Wasatiyah Centre for Peace; 08/FRGS 03/2018.

\section{References}

1. Abdul Rauf Ridzuan, Jusang Bolong \& Al-Mansor Abu Said. (2017). The level of cyber ethnocentrism among multiethnic in Malaysia. Academic Journal of Business and Social Sciences, 1(Sept. 2017).

2. Abdul Razaq Ahmad. (2018). Malaysia-Molded Patriotism Framework. Proceeding of the 2nd URICES, Pekanbaru, Indonesia (pp 11-17).

3. Adlina Abdul Khalil, Rosfazila Abd Rahman \& Hairol Anuar Mak Din. (2018). Kajian kes interaksi sosial dalam kalangan pelajar pelbagai etnik ke arah pengukuhan integrasi nasional. Malaysian Journal of Social Sciences and Humanities, 3(3), 131-135.

4. Bagong Suyanto. (2016). Potential threats to social harmony in Johor, Malaysia. Pertanika Journal of Social Science \& Humanities, 24(4), 1737-1751.

5. Berg, B. L. (2007). Qualitative research methods for the social sciences (Ed. ke-6). Boston: Allyn \& Bacon.

6. Bilveer Singh. (2015). Prevention of terrorism: Relevance of POTA in Malaysia. (RSIS Commentaries, No. 075). RSIS Commentaries. Singapore: Nanyang Technological University.

7. Carlsson, L., Lannerstrom, L., Wallman, T., \& Holmstrom, I. K. (2015). General practitioners' perceptions of working with the certification of sickness absences following changes in the Swedish social security system: A qualitative focus-group study. BMC Family Practice. doi 10.1186/s12875-015-02385.

8. Creswell, J. W. (2008). Educational research: Planning, conducting, and evaluating quantitative and qualitative research (3rd ed.). Upper Saddle River, NJ: Pearson Education, Inc.

9. Creswell, J. W. (2012). Qualitative inquiry and research design: Choosing among five approaches. London: SAGE Publications.

10. Fazilah Idris, Mohd Richard Neles Abdullah, Abdul Razak Ahmad \& Ahmad Zamri Mansor. (2016). The effect of religion on ethnic tolerance in Malaysia: The application of Rational Choice Theory (RCT) and the Theory of Planned Behaviour (TPB). International Education Studies, 9(11), 13-24.

11. Ghazali Lateh \& Shamsudin Othman. (2014). A study of verbal interactions among Malaysia teenagers based on the ethnography of communications. Jurnal Pendidikan Bahasa Melayu, 4(1), 30-40.

12. Hussein Ahmad \& Hanieza Ab. Hamid. (2017). Pengurusan pembangunan konsep perpaduan dalam kalangan pelajar sekolah menengah kebangsaan: Satu kajian di Klang, Selangor. Jurnal Kepimpinan Pendidikan, 2(4), 1-15.

13. Jazimin Zakaria \& Sity Daud. (2018). Social decohesion and democracy: Renunciation of national integration in a pluralist society. International Journal of Advanced Scientific Research and Management, 3(3), 6-10.

14. Junaidi Awang Besar, Rosmadi Fauzi, Amer Saifude Ghazali, Mohd Azlan Abdullah, Mazlan Ali \& Ahmad Rizal Mohd Yusof. (2014). Malaysia's General Election(GE) 2013: An analysis of urban political 'tsunami'. Malaysian Journal of Society and Space, 10, 28-38.

15. Khairul Anuar Shamsuddin, Jessica Ong Hai Liaw \& Ahmad Azan Ridzuan. (2015). Malaysia: Ethnic issues and national security. International Journal of Humanities and Social Science, 5(9), 136-143.

16. Mahyuddin Ahmad. (2011). Between desire and hope: Ethnic relations and the notion of bangsa Malaysia in Gadoh. Kajian Malaysia, 29(1), 75-90.

17. Mohd Azmir Mohd Nizah. (2015). On Malaysia's ethnic tolerence: A study of two cities. Research Journal of Applied Sciences, 10(8), 294-297.

18. Mohd Azrone Sarabatin. (2018, November 29). Kontrak sosial, jus soli wujud hasil toleransi. Diambil daripada https://www.bharian.com.my/kolumnis/2018/11/ 503249/kontrak-sosial-jus-soli-wujud-hasiltoleransi. 
19. Mohd Ridhuan Tee Abdullah. (2015). Cabaran integrasi antara kaum di Malaysia: Perspektif media, pertubuhan bukan kerajaan dan parti politik. Jurnal Hadhari, 7(1), 33-60.

20. Nazri Muslim \& Ahmad Hidayat Buang. (2012). Islam dalam Perlembagaan Persekutuan dari perspektif hubungan etnik di Malaysia. Jurnal Kemanusiaan, 20, 115-129.

21. Nidzam Sulaiman \& Kartini Aboo Talib @ Khalid. (2017). Will there be Malaysia spring? A comparative assessment on social movements. Malaysian Journal of Communication, 33(1), 43-58.

22. Noralina Omar. (2016). Ekologi keluarga dan kesejahteraan hidup kanak-kanak miskin di Malaysia (Tesis doktoral). Universiti Malaya, Kuala Lumpur.

23. Nur Farhana Abdul Rahman \& Khadijah Mohd Khambali @ Hambali. (2013). Religous tolerence in Malaysia: Problems and challanges. International Journal of Islamic Thought, 3(June), 81-91.

24. Nyumba, T. O., Wilson, K., Derrick, C. J, \& Mukherjee, N. (2018). The use of focus group discussion methodology: Insights from two decades of application in conservation. Methods in Ecology and Evolution, 9, 20-32.

25. Patton, M. Q. (2002). Qualitative research and evaluation methods (Ed. ke-3). Thousand Oaks: Sage Publications.

26. Rokiah Abdullah. (2018, Ogos 7). Elak ungkit kontrak sosial. Diambil daripada http://www.utusan.com.my/berita/nasional/elak-ungkit-kontrak-sosial-1.724148.

27. Sabitha Marican. (2006). Penyelidikan sains sosial. Batu Caves: Edusystem Sdn. Bhd.

28. Sarjit S. Gill, Mohd Rahimi Ramli \& Ahmad Tarmizi Talib. (2015). Kesedaran patriotik dalam kalangan belia bandar di Semenanjung Malaysia. Jurnal Sosial Ilmu Politik, 1(1), 111-120.

29. Schensul, S. L., Schensul, J. J., \& LeCompte, M. D. (1999). Essential ethnographic methos: Ethnographer's toolkit. New York: Altamira Press.

30. Shamsul Amri Baharuddin. (2012). Hubungan etnik (Ed. ke-2). Bangi: Institut Kajian Etnik UKM.

31. Siti Shariyah Shaari, Junaidi Awang Besar \& Mohd Fuad Mat Jali. (2017). Analisis keberkesanan subjek Hubungan Etnik sebagai pencetus literasi politik: Kajian ke atas mahasiswa UNIKL MIIT. Journal of Social Sciences and Humanities, Special Issue 2, 26-33.

32. Suseela Malakolunthu. (2001). Pengumpulan dan analisis data kualitatif: Satu imbasan. Dalam Marohaini Yusoff (Ed.), Penyelidikan kualitatif: Pengalaman kerja lapangan kajian. Kuala Lumpur: Penerbit Universiti Malaya.

33. Suzy Aziziyana Saili, Rosila Bee Mohd Hussain \& Khairulnizam Mat Karim. (2018). The role of communities liaison committee in pioneering social cohesion in Malaysia: An initial review for a future model. Malaysian Journal of Social Sciences and Humanities (MJSSH), 3(3), 160-167.

34. Teo Kok Seong. (2018, November 25). Hargai kontrak sosial. Diambil daripada http://www.utusan.com.my/rencana/utama/hargailah-kontrak-sosial-1.793362.

35. Tiung, L. K., \& Mohd Safar Hasim. (2015). The role of Chinese newspapers in the articulation of historical issues and the formation of the nation-state. Malaysian Journal of Communication, 31(1), 257280.

36. Weiss, M. R., Smith, A. L., \& Theeboom, M. (1996). That's what friends are for: Children's and teenagers' perception of peer relationships in the sport domain. Journal of Sport \& Exercise Psychology, 18, 347379.

37. Zahrul Akmal Damin, Fauziah Ani, Lutfan Jaes, Khairunesa Isa, Siti Sarawati Johar, Harliana Halim, Shamsaadal Sholeh Saad, Ku Hasnan Ku Halim, Khairul Azman Mohd Suhaimy, Md. Akbal Abdullah, Khairol Anuar Kamri, Nur Azah Razali, Norafitri Md. Nor, Shahidah Hamzah \& Rosman Md Yusoff. (2016). Kenegaraan dan pembangunan mutakhir Malaysia. Baru Pahat: Penerbit UTHM.

38. Zahrul Akmal Damin. (2016). Dasar kerajaan dan isu sekuriti makanan di Malaysia: Kajian analisis dokumen dan temubual (Tesis doktoral). Universiti Utara Malaysia, Kedah.

39. Zhang, Y., \& Wildemuth, B. M. (2015). Qualitative analysis of content. Dlm. B. M. Wildemuth (Ed.), Application of social research methods to questions in information and library science (pp. 318-329). California: Libraries Unlimited. 